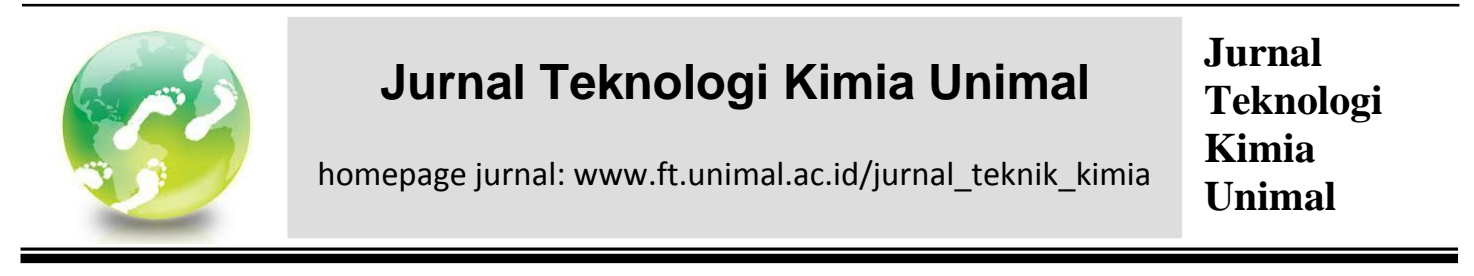

\title{
PROSES EKSTRAKSI MINYAK DARI BIJI PEPAYA (CARICA PAPAYA) DENGAN MENGGUNAKAN PELARUT n-HEKSANA
}

\author{
Azhari, Nilva Mutia, Ishak \\ Jurusan Teknik Kimia Universitas Malikussaleh, Kampus Bukit Indah Lhokseumawe \\ Coresponden: nilvamutia@gmail.com
}

\begin{abstract}
Papaya is the most beneficial fruit for human health. In addition to the fruit that can be consumed, it turns out papaya seeds can also be used. In addition to the seeds used to be planted as well as only being waste, oil can also be obtained from papaya seeds. One method for obtaining papaya seed oil is a method of extracting heat (requires installation in the process), in general the notion of reflux is extraction with a solvent at its boiling temperature point, for a certain time and the amount of solvent adjusted to air temperature. In this research, papaya seed extraction was carried out, percent yield analysis was carried out, and heavy type analysis of papaya seed oil extraction was carried out. The purpose of this study was to study the variation in extraction time of papaya seeds with solvents on the yield of oil produced. This research was carried out by reacting papaya seeds with hexane solvents at 65 ${ }^{\circ} \mathrm{C}$. Where the weight of papaya seeds is $50 \mathrm{gr}$, and the volume of solvents varied by $300 \mathrm{ml}$, $400 \mathrm{ml}$, and $500 \mathrm{ml}$ and the reaction time is 120 minutes, 150 minutes, and 180 minutes. The results showed that the largest papaya seed oil was $34.2 \%$ at a volume of $500 \mathrm{ml}$ solvent for 180 minutes and a high density of $0.87 \mathrm{gr} / \mathrm{ml}$ at a volume of $500 \mathrm{ml}$ solvent for 180 minutes.
\end{abstract}

Keywords: Extraction, hexane, papaya seed oil, reflux

Abstrak. Pepaya merupakan buah paling banyak manfaat bagi kesehatan manusia.
Selain daging buahnya yang dapat dikonsumsi, ternyata biji pepaya juga dapat
dimanfaatkan. Selain biji digunakan untuk ditanam serta hanya menjadi limbah
buangan, ternyata biji pepaya juga dapat memperoleh minyak. Salah satu metode
untuk memperoleh minyak biji pepaya adalah metode ekstraksi cara panas
(membutuhkan pemanasan pada prosesnya), secara umum pengertian refluks adalah
ekstraksi dengan pelarut pada temperatur titik didihnya, selama waktu tertentu dan
jumlah pelarut yang relatif konstan dengan adanya pendingin balik. Pada penelitian
ini dilakukan proses ekstraksi biji pepaya, dimana dilakukan analisa persen
rendemen, dan analisa berat jenis dari hasil ekstraksi minyak biji pepaya. Tujuan dari
penelitian ini adalah mengetahui pengaruh variasi waktu ekstraksi biji pepaya dengan 
pelarut terhadap rendemen minyak yang dihasilkan. Penelitian ini dilakukan dengan mereaksikan biji pepaya dengan pelarut heksana pada suhu $65^{\circ} \mathrm{C}$. Dimana berat biji pepaya $50 \mathrm{gr}$, serta konsentrasi volume pelarut yang divariasikan $300 \mathrm{ml}, 400 \mathrm{ml}$, dam $500 \mathrm{ml}$ dan waktu reaksi 120 menit, 150 menit, dan 180 menit. Hasil penelitian menunjukkan bahwa rendemen minyak biji pepaya terbesar adalah 34,2\% pada volume pelarut $500 \mathrm{ml}$ selama 180 menit dan densitas yang tinggi yaitu $0,87 \mathrm{gr} / \mathrm{ml}$ pada volume pelarut $500 \mathrm{ml}$ selama 180 menit.

Kata kunci: Ekstraksi, heksana, minyak biji pepaya, refluks

\section{Pendahuluan}

Pepaya merupakan buah yang beragam manfaat bagi masyarakat selain banyak mengandung vitamin A, ternyata buah sehat ini juga dimanfaatkan sebagai obat dalam berbagai macam penyakit. Pada umumnya, masyarakat hanya mengetahui bahwa daging buahnya saja yang dapat dikonsumsi. Namun ternyata biji pepaya juga dapat dimanfaatkan. Selain biji digunakan untuk ditanam serta hanya menjadi limbah buangan, ternyata biji pepaya juga dapat diolah menjadi minyak.

Tanaman pepaya termasuk komoditas utama dari kelompok buah-buahan yang mendapat prioritas penelitian dan pengembangan di lingkungan Puslitbang holtikultura. Dalam berat kering biji pepaya mengandung minyak $25 \%$. Jika dibandingkan dengan kedelai 19,63\% dan biji bunga matahari 22,23\% maka kandungan minyak dalam biji pepaya relatif besar sehingga sangat prospek untuk dikembangkan menjadi bahan bakar alternatif (Rahayu, 2009). Sedangkan biji pepaya yang sering dijumpai dimasyarakat hanya sebagai limbah yang kurang bermanfaat. Sehingga perlu adanya penanganan, untuk memaksimalkan manfaat dari biji pepaya tersebut.

Pengambilan minyak dari biji pepaya dapat dilakukan dengan metode sokhelet ekstraksi, dan metode reflux ekstraksi. Dalam penelitian ini metode yang digunakan adalah reflux ekstraksi, metode ini umumnya digunakan untuk mensistesis senyawa-senyawa yang mudah menguap atau volatile. Pada kondisi ini jika dilakukan pemanasan biasa maka pelarut akan menguap sebelum reaksi berjalan sampai selesai. Prinsip dari metode refluks adalah pelarut volatil yang digunakan akan menguap pada suhu tinggi, namun akan didinginkan dengan kondensor sehingga pelarut yang tadinya dalam bentuk uap akan mengembun pada kondensor dan turun lagi ke dalam wadah reaksi sehingga pelarut akan tetap ada selama reaksi berlangsung. Pelarut akan berpenetrasi ke dalam biji pepaya dan menghasilkan minyak biji pepaya. Minyak 
hasil ekstraksi dengan pelarut mempunyai keunggulan yaitu mempunyai bau yang mirip bau alamiah. Seperti ekstraksi minyak tumbuhan pada umumnya, ekstraksi minyak biji pepaya menggunakan pelarut organik seperti heksana. Pelarut ini bersifat inert, memiliki titik didih yang rendah serta dapat melarutkan dengan cepat dan sempurna. Namun, penggunaan pelarut organik beracun dalam proses pengolahan makanan harus dibatasi.

Pada biji pepaya terdapat sebuah senyawa yang dihaluskan diyakini mampu melawan cacing parasit di usus, yaitu benzyl isothiocynate, telah terbukti memiliki efek pada kontraksi pembuluh darah menggunakan arteri karotis dalam model in vitro (Samarama Shadi, dkk, 2014). Dari biji pepaya juga dapat menghasilkan minyak yang dapat mengurangi tekanan darah, membantu pembakaran lemak, mencegah ulcerative colitis (peradangan usus), meringankan diabetes type 2, melindungi membran sel dari readikal bebas. Pada bidang kesehatan minyak biji pepaya dapat digunakan untuk pelembab kulit, meningkatkan pertumbuhan rambut, dan anti penuaan pada kulit (Sebastian Johan, 2018). Pepaya mengandung berbagai jenis enzim, vitamin serta asam lemak dan juga berbagai zat-zat kimia lainnya pada berbagai bagian pepaya, seperti pada buah, daun, bunga, biji, akar, dan kulit. Buah pepaya memiliki kandungan 30,1\% minyak, $28,1 \%$ protein, $19,1 \%$ serat, $25,6 \%$ karbohidrat, 7,3\% kandungan air, dan 8,2\% abu (Krishna, dkk, 2008). Komposisi kimia dalam buah pepaya dapat dilihat pada Tabel 2.2.

Table 2.2 Komposisi Kimia Buah Pepaya

\begin{tabular}{|c|c|}
\hline Komposisi Kimia & Nilai (\%) \\
\hline Air & 7,3 \\
\hline Protein & 28,1 \\
\hline Minyak & 30,1 \\
\hline Abu & 8,2 \\
\hline Serat & 19,1 \\
\hline Total karbon & 25,6 \\
\hline
\end{tabular}

Sumber: Syed, dkk, 2012. 


\section{Metodologi}

Bahan yang digunakan pada penelitian ini adalah biji pepaya dan larutan heksana. Metode yang digunakan ada tiga tahap. Tahap pertama proses ekstraksi biji pepaya, tahap kedua distilasi dan tahap ketiga analisa rendemen, berat jenis, dan uji GC-MS . Variabel tetap yang digunakan adalah berat biji pepaya 50 gr (pepaya madu), suhu ekstraksi $65{ }^{\circ} \mathrm{C}$, suhu distilasi $70{ }^{\circ} \mathrm{C}$ dan waktu distilasi 60 menit. Variabel bebas yang digunakan adalah volume pelarut Heksana ( 300 ml, 400 ml, dan $500 \mathrm{ml}$ ) dan waktu ekstraksi 120 menit, 150 menit, dan 180 menit.

\section{Hasil dan pembahasan}

\section{1 pengaruh waktu dan volume pelarut terhadap rendemen}

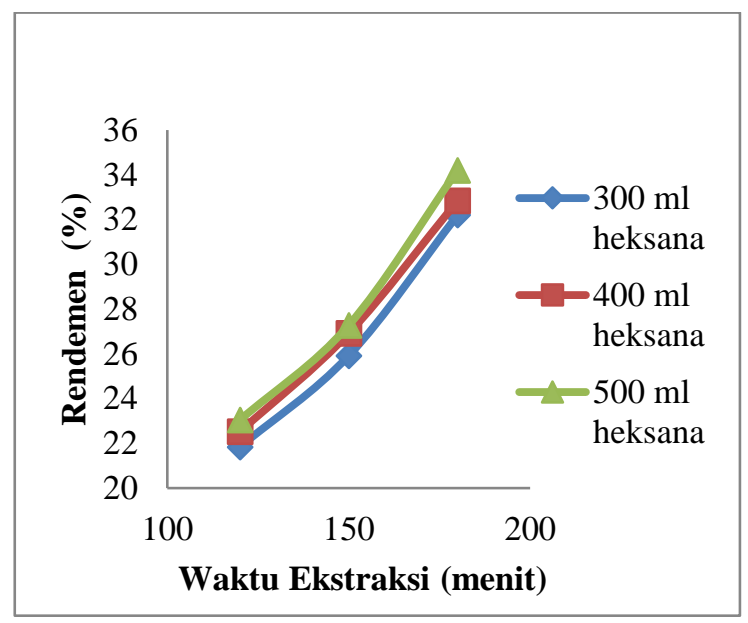

Gambar 1. Pengaruh Waktu Ektraksi dan Volume Pelarut Terhadap Persen Rendemen Minyak Biji Pepaya

Gambar 1 menunjukkan bahwa waktu ekstraksi dan jumlah pelarut yang digunakan sangat mempengaruhi \% rendemen minyak yang dihasilkan dari biji pepaya dengan metode ekstraksi. Hal ini dapat dijelaskan bahwa untuk mendapatkan kandungan minyak yang lebih banyak, diperlukan waktu ekstraksi yang lebih lama pula agar terjadi waktu kontak yang lama antara biji pepaya dengan pelarut yang memberikan kesempatan biji pepaya untuk kontak dengan pelarut semakin besar sehingga kandungan minyak dapat diekstrak secara maksimum.

Pada waktu ektraksi yang tetap dengan peningkatan perbandingan pelarut terhadap biji pepaya menyebabkan kandungan minyak meningkat. Hal ini dapat 
dijelaskan bahwa pelarut harus banyak tersedia selama proses ekstraksi agar dapat memaksimalkan kandungan minyak yang diekstrak. Semakin banyak pelarut yang digunakan, maka akan mengurangi tingkat kejenuhan.

Hasil terbaik yang didapat adalah pada waktu ekstraksi 180 menit dengan volume pelarut yang digunakan $500 \mathrm{ml}$, dimana \% rendemen yang dihasilkan yaitu $34,2 \%$ dan rendemen yang paling rendah pada waktu 120 menit dengan volume pelarut $300 \mathrm{ml}$. Hal ini menunjukkan bahwa semakin lama waktu ekstraksi maka semakin tinggi \% rendemen minyak yang dihasilkan, dikarenakan semakin lama waktu ekstraksi maka pengontakan yang terjadi antara bahan dengan pelarut berlangsung lama, sehingga kandungan minyak yang ada pada bahan akan banyak terekstrak dalam pelarut.

\subsection{Pengaruh waktu dan volume pelarut terhadap densitas minyak}

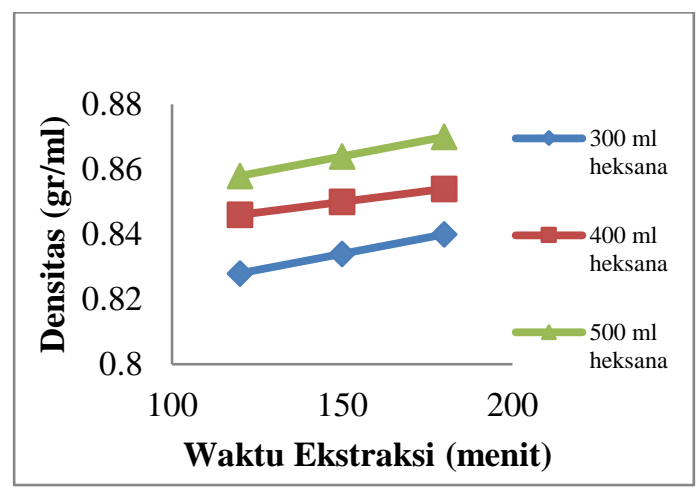

Gambar 2. grafik pengaruh waktu dan volume pelarut terhadap densitas minyak

Gambar 2 menunjukan analisa berat jenis yang diperoleh berbeda-beda berdasarkan lama waktu ekstraksi dan volume pelarutnya. Berat jenis menjelaskan banyaknya komponen yang terkandung dalam zat tersebut. Menurut Simbolon (2012), besar kecilnya nilai berat jenis sering dihubungkan dengan fraksi berat komponen-komponen yang terkandung didalamnya. Maka dari itu, apabila semakin besar fraksi berat yang terkandung dalam minyak, maka semakin besar pula nilai berat jenisnya. Adapun nilai berat jenis yang terbesar adalah hasil ekstraksi dengan volume $500 \mathrm{ml}$ selama 180 menit, yaitu sebesar 0,87 gr/ml, sedangkan berat jenis yang terendah didapat pada volume ekstraksi $300 \mathrm{ml}$ selama 120 menit yaitu, 0,828 $\mathrm{gr} / \mathrm{ml}$. 
Semakin lama waktu ekstraksi maka semakin tinggi berat jenis minyak biji pepaya yang didapat. Nilai berat jenis cenderung naik dengan bertambahnya volume pelarut. Hal ini dikarenakan semakin lama waktu ektraksi dan semakin banyak volume pelarut maka semakin banyak komponen yang terekstraksi dari dalam biji pepaya sehingga menaikkan nilai berat jenisnya. Jadi dapat dikatakan bahwa semakin lama waktu dan semakin besarnya volume pelarut maka semakin tinggi berat jenis yang di dapat.

\subsection{Analisa Komposisi Minyak Biji Pepaya dengan GC-MS (Gas Chromatography Mass Spectrofotometry)}
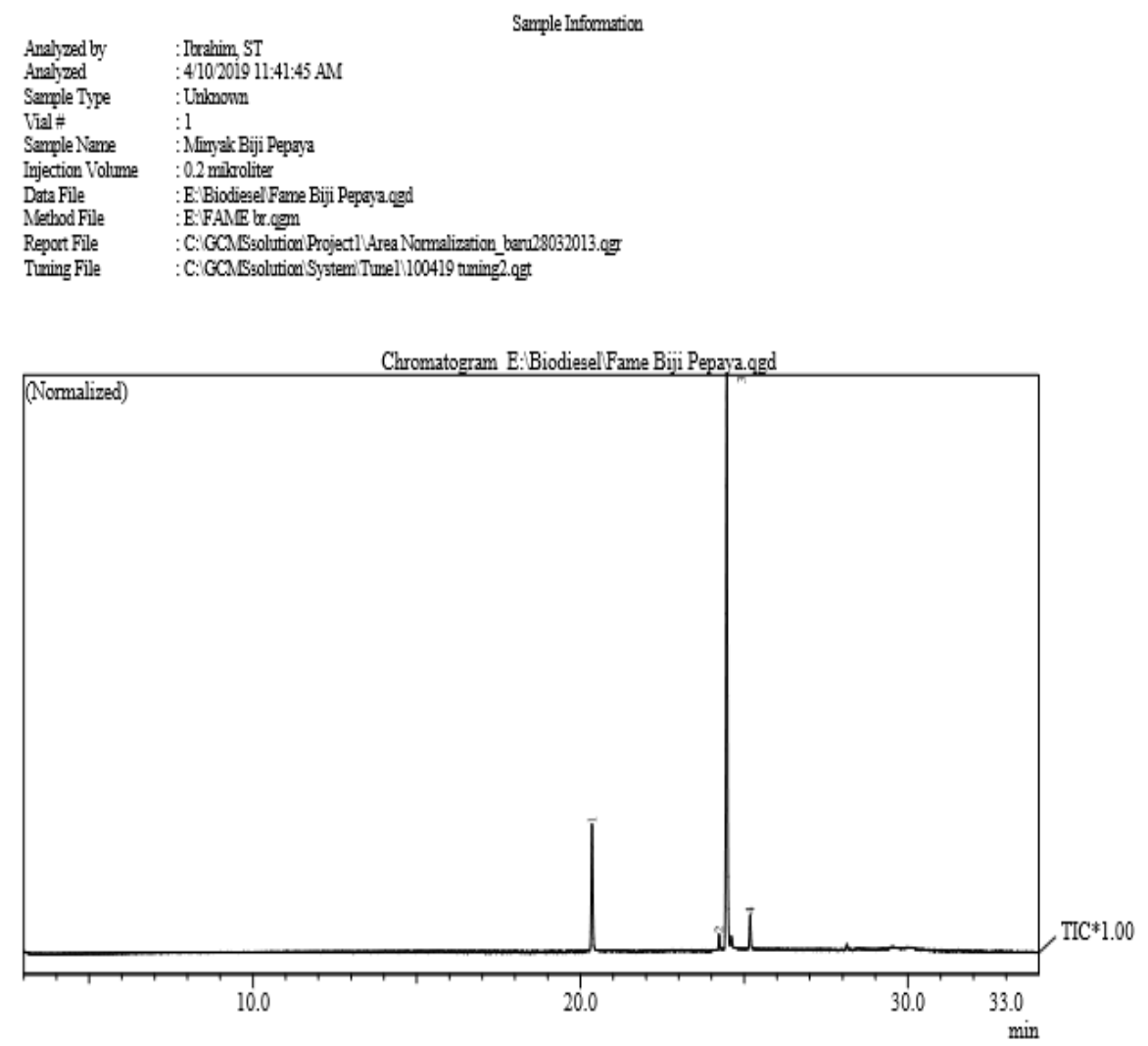

Peak Report TIC

\begin{tabular}{|c|r|r|l|l|l|}
\hline Pealk & R.Time & Area & Area\% & Name \\
\hline 1 & 20.354 & 413785 & 15.97 & Hexadecanoic acid, methyl ester (CAS) Methyl palmitate \$S Methyl hexadecanoate \\
\hline 2 & 24.234 & 41364 & 1.60 & Cyclohexane, methylene-(CAS) Methylenecyclohexane S\$ METHYLENE-CYCLOHEXANE \\
\hline 3 & 24.465 & 2021984 & 78.06 & 9-Octadecenoic acid (Z)-, methyl ester (CAS) Methyl oleate \$S Oleic acid methyl ester \\
\hline 4 & 25.179 & 113228 & 4.37 & Octadecanoic acid, methyl ester (CAS)Methyl stearate \$\$ Stearic acid methyl ester \\
\hline & & 2590361 & 100.00 & \\
\hline
\end{tabular}

Gambar 3. grafik analisa uji gc-ms 
Gambar 3. menunjukkan hasil GC-MS empat komponen utama pada minyak biji pepaya, diperoleh Hexadecanoic acid, methyl ester (CAS) Methyl palmitate \$\$ Methyl hexadecanoate sebesar 15,97 \% pada waktu reserensi 20, 354 menit. Cyclohexane, methylene- (CAS) Methylenecyclohexane \$ METHYLENECYCLOHEXANE sebesar 1,60 \% pada waktu reserensi 24,234 menit, 9Octadecenoic acid (Z)-, methyl ester (CAS) Methyl oleate \$\$ Oleic acid methyl ester sebesar 78,06 \% pada waktu reserensi 24,465 menit, Octadecanoic acid, methyl ester (CAS) Methyl stearate \$ Stearic acid methyl ester sebesar 4,37 \% pada waktu reserensi 25,179 menit.

Kandungan metil ester terbesar yang diperoleh yaitu metil oleat dengan presentase area sebesar 78,06 \% pada waktu reserensi 24,465 menit, ini menunjukkan minyak biji pepaya mengandung asam oleat. Asam oleat mempunyai rumus kimia $\mathrm{C}_{18} \mathrm{H}_{34} \mathrm{O}_{2}$ dan merupakan fatty acid memiliki satu ikatan ganda. Asam oleat yang di dapat pada minyak biji pepaya dalam penelitian ini lebih tinggi jika dibandingkan dengan penelitian yang terdahulu yang menggunakan pelarut petroleum ether dengan presentase asam oleat sebesar 71,30\% (Malacrida, dkk, 2010).

\section{Kesimpulan}

1. Variasi waktu dan volume pelarut berpengaruh terhadap rendemen minyak yang dihasilkan. Ekstraksi pada menit ke-180 dengan volume pelarut yaitu $500 \mathrm{ml}$.

2. Semakin lama waktu ekstraksi maka semakin tinggi berat jenis minyak biji pepaya serta semakin besar persen rendemen yang didapatkan.

3. Semakin besar volume pelarut maka semakin tinggi berat jenis dan rendemen yang di dapatkan.

4. Berat jenis yang diperoleh pada volume pelarut $500 \mathrm{ml}$ selama 180 menit yaitu $0,87 \mathrm{gr} / \mathrm{ml}$.

5. Rendemen minyak biji pepaya yang tertinggi didapat pada volume pelarut $500 \mathrm{ml}$ selama 180 menit yaitu 34,2 


\section{Daftar Pustaka}

Edward A. Evans And. Ballen H Fredy. 2012." An Overview of Global Papaya Production, Trade, and Consumption"First. McGraw-Hill Book Company. New York.

Day, J. R., dan Underwood, A.L. 1998. Quantitative Analysis Sixth Edition. Emeritus: Emory University.

Hendayana, S. 2006. Kimia Pemisahan Metode Kromatografi dan Elektroforesis Modern. Bandung: PT. Remaja Rosda Karya.

I.S Afolabi, and Ofobrukweta, K. 2011." Physicochemical and nutritional qualities of Carica papaya seed products". Journal of Medicinal Plants Research Vol. Vol. 5(14), pp. 3113-3117.

Khopkar, S. M. 1990. Konsep Dasar Kimia Analitik. Jakarta: Penerbit Universitas Indonesia. Hal. 216-217.

Krishna K L, M Paridhavi, and Jagruti A Patel. 2008."Review on nutritional, medicinal and pharmacological properties of Papaya (Carica papaya Linn.). Natural Product Radiance, Vol. 7(4), pp.364-373.

Lee Wei-Ju, Min-Hsiung Lee, and Nan-Wei Su. 2011."Characteristics of papaya seed oils obtained by extrusion-expelling processes". J Sci Food Agric; 91: 23482354.

Mulja, M., H. 1994. Perkembangan Instrumentasi Kromatografi Gas. Surabaya: Universitas Airlangga.

Malacrida Roberta Cassia., Kimura Mieko.,dan Jorge Neuza. 2010. "Characterization of a high oleic oil extracted from papaya (Carica papaya $L$.) seeds". Department of Food Engineering and Technology, São Paulo State University - UNESP. Vol: 31(4), pp : 929-934.

Milind Parle and Gurditta. 2011."Basketful Benefits Of Papaya". International Research Journal Of Pharmacy, vol 2(7), pp : 6-12 
Purwanto sigit, Ekstraksi Minyak Dari Biji Papaya (Carica Papaya) Dengan Metode Soxhlet Extraction Dengan Mengunakan n-Butil Asetat, Universitas Sumatera Utara, Medan: 2016.

Samarama Shadi, Hamed Mirhosseinia, Chin Ping Tana, Hasanah Mohd Ghazali. 2014. "Ultrasound-assisted extraction and solvent extraction of papaya seedoil: Crystallization and thermal behavior, saturation degree, color andoxidative stability". Industrial Crops and Products 52, 702- 708.

Sebastian Johan, Pengeringan Biji Pepaya Dan Pengaruh Metode Ekstraski Terhadap Persentase Yield Minyak Biji Pepaya. Universitas Katolik Parahyangan, Bandung: 2018

Syed H.M., Kunte S.P., Jadhav B.A., dan Salver R.V. 2012.“Extraction End Charactization Of Papaya Seed Oil". International Journal Of Applied, Physical And Bio-Chemistry Research Vol.2, pp: 33-43.

Yazid, E. 2005. Kimia Fisika Untuk Paramedis. Yogyakarta: ANDI Press. 